\title{
Increased expression of urotensin II and GPR14 in patients with cirrhosis and portal hypertension
}

\author{
DIANGANG LIU ${ }^{1,2^{*}}$, JING CHEN $^{3,4^{*}}$, JIN WANG $^{2}$, ZHONGTAO ZHANG $^{2}$, \\ XUEMEI MA ${ }^{2}$, JIDONG JIA ${ }^{3 * *}$ and YU WANG ${ }^{2 * *}$ \\ ${ }^{1}$ Department of General Surgery, Xuan Wu Hospital, Capital Medical University, Beijing; ${ }^{2}$ Department of \\ General Surgery; ${ }^{3}$ Liver Research Center, Beijing Friendship Hospital, Capital Medical University, \\ Beijing; ${ }^{4}$ Department of Gastroenterology, the Second Affiliated Hospital of \\ Harbin Medical University, Harbin, Heilongjiang Province, P.R. China
}

Received January 7, 2010; Accepted February 26, 2010

DOI: 10.3892/ijmm_00000413

\begin{abstract}
Urotensin II (UII) and its receptor (UT or GPR14) are involved in liver fibrosis and portal hypertension. Nevertheless, expression of the UII/UT system in the liver of patients with portal hypertension has not been elucidated. UII and UT gene expression were quantified in liver biopsy samples from patients with hepatitis-B-virus-associated cirrhosis and portal hypertension, and from normal controls by using quantitative real-time PCR. The liver distribution of UT was determined by means of immunohistochemistry and immunofluorescence. Western blot analysis was used to assess liver levels of UT. Simultaneously, we measured intraoperative free portal venous pressure (FPVP) and collected plasma for UII measurement by ELISA. UT expression at the mRNA and protein level was enhanced significantly in the liver of patients with cirrhosis and portal hypertension, compared with that in healthy controls. UT protein expression was concentrated mainly in the Kupffer cells and sinusoidal endothelial cells. In cirrhotic tissue, UII gene expression was increased 5-fold in comparison to that in normal liver tissue. Plasma UII level was higher in cirrhotic patients compared with controls and was correlated with FPVP $(r=0.807 ; \mathrm{P}<0.001)$ and UII mRNA in the liver $(\mathrm{r}=0.802 ; \mathrm{P}<0.001)$. These findings suggest that the intrahepatic UII/UT system has an important pathophysiological role in cirrhosis and portal hypertension.
\end{abstract}

Correspondence to: $\mathrm{Dr} \mathrm{Yu}$ Wang, Department of General Surgery, Beijing Friendship Hospital, Capital Medical University, 95 Yong-An Road, Beijing 100050, P.R. China

E-mail:wangyu0319@hotmail.com

Contributed equally

${ }^{* *}$ Share senior authorship

Abbreviations: FPVP, free portal venous pressure; UII, urotensin II; UT, urotensin II receptor

Key words: liver cirrhosis, portal hypertension, urotensin II, GPR14

\section{Introduction}

Increased intrahepatic resistance is the initial event of increased portal pressure and development of portal hypertension in cirrhosis $(1,2)$. Careful pathological studies have demonstrated that, in addition to the increased resistance caused by morphological changes in chronic liver diseases, a dynamic component of increased resistance is present that represents active contraction of contractile elements in the liver. These elements constrict in a reversible and graded manner in response to several agonists, thereby further increasing the intrahepatic resistance $(3,4)$. Several vasoconstrictors, such as angiotensin II and endothelin (ET), have been shown to be involved in the increased vascular tone in cirrhosis (5-7). The most recent addition to this expanding family of vasomodulatory substances is urotensin II (UII), a somatostatin-like cyclic undecapeptide, which has been identified as the most potent mammalian vasoconstrictor known (8). In addition to its effects on vascular tone, UII possesses mitogenic and fibrogenic potential (9). In vivo and in vitro studies have suggested that UII has a role in myocardial and vascular remodeling associated with cardiovascular diseases $(10,11)$.

Although originally isolated from the urophysis of teleost fish, UII peptides have been highly conserved through evolution from fish to humans (12). Conservation of this cyclic hexapeptide suggests a significant physiological function for UII. The identification in 1999 of human UII as the cognate ligand for the novel G-protein-coupled receptor GPR14 (renamed urotensin II receptor, UT) has been followed by rapid exploration of the UII/UT system in human diseases (8). The observation that basal hemodynamics and general vasopressor responsiveness are unaltered in UT knockout mice supports the suggestion that the receptor is functionally silent under basal conditions, but this may change in cardiovascular diseases (13). In addition to elevated levels in patients with heart failure, systemic hypertension, diabetes mellitus, and renal failure $(14,15)$, increased plasma UII levels have been reported in patients with cirrhosis $(16,17)$.

However, although plasma levels of UII are upregulated in cirrhosis, their physiological relevance is unclear. The expression of the UII/UT system in the liver of patients with 
portal hypertension has not been elucidated. Accordingly, the present study sought to determine the expression of UII and UT in patients with cirrhosis and portal hypertension.

\section{Materials and methods}

Patients and tissue collection. With local research ethics committee approval and written informed consent, we recruited 23 patients (seven female) with portal hypertension and hepatitis-B-virus-associated cirrhosis. All 23 patients had histological or clinical evidence of cirrhosis and portal hypertension. They underwent transabdominal esophagogastric devascularization and splenectomy because of variceal bleeding (first to fourth event pre-admission). Control tissue was obtained from surplus liver biopsy material that was obtained for diagnostic purposes from 10 living donors before liver transplantation. All normal control subjects had normal liver function, were normotensive, and had no evidence of liver fibrosis (Table I). Patients with diabetes mellitus, chronic kidney disease (creatinine $>177 \mathrm{mmol} / \mathrm{l}$; blood urea nitrogen $>9 \mathrm{mmol} / \mathrm{l}$ ), systemic hypertension, and aortic valvular diseases were excluded. Biopsy specimens were divided into two portions. One portion was immediately snap frozen and stored in liquid nitrogen for subsequent RNA extraction. A second portion was fixed in neutral buffered formalin and embedded in paraffin for later immunohistochemical analysis. Blood ( $5 \mathrm{ml}$ ) was collected from each patient's forearm vein into tubes that contained EDTA and aprotinin $(0.6 \mathrm{TIU} / \mathrm{ml}$ of blood) after induction of anesthesia and tracheal intubation. Blood samples were maintained on ice before centrifugation at $3,000 \mathrm{x} \mathrm{g}$ for $20 \mathrm{~min}$ at $4^{\circ} \mathrm{C}$, after which plasma was removed and stored at $-80^{\circ} \mathrm{C}$.

RNA extraction and complementary DNA synthesis. Frozen liver biopsy tissues, stored in liquid nitrogen, were homogenized. Total RNA was extracted from snap-frozen liver biopsy specimens by using the Trizol Reagent kit (Invitrogen Life Technologies, Carlsbad, CA, USA). The amount of RNA recovered was quantitated, and its quality was verified by ultraviolet absorbance spectrophotometry at 260 and $280 \mathrm{~nm}$. The cDNA was reverse transcribed using the High-Capacity cDNA Reverse Transcription Kits (Applied Biosystems, Foster City, CA, USA), according to the manufacturer's instructions. Reactions were as follows: $25^{\circ} \mathrm{C}$ for $10 \mathrm{~min}, 37^{\circ} \mathrm{C}$ for $150 \mathrm{~min}$, $85^{\circ} \mathrm{C}$ for $5 \mathrm{sec}$, and $4^{\circ} \mathrm{C}$ for $5 \mathrm{~min}$ before chilling on ice. The cDNA was stored at $-20^{\circ} \mathrm{C}$ for future use.

Real-time PCR (SYBR Green). UII and UT gene expression were quantified by means of real-time PCR. The sequences of the primers used are shown in Table II. GAPDH, a housekeeping gene, was used as an internal control primer for target genes. All primers were obtained from Invitrogen (Beijing, China). The expression of candidate gene mRNA was measured by SYBR Green real-time PCR using an ABI 7500 instrument (Applied Biosystems), according to the manufacturer's instructions. The PCR was performed in $20 \mu \mathrm{l}$ buffer that contained $2 \mu \mathrm{g}$ cDNA, $1 \mu \mathrm{l}$ of each primer, and $10 \mu \mathrm{l}$ SYBR Green PCR Master Mix (Applied Biosystems). Comparative cycle threshold $(\mathrm{Ct})$ calculations were all relative to the control group. GADPH $\mathrm{Ct}$ values were subtracted from gene $\mathrm{Ct}$ values to give a final $\mathrm{Ct}$ value. $\Delta \Delta \mathrm{Ct}$ values were achieved by subtracting the average control $\Delta \mathrm{Ct}$ value, and expression of UII and UT relative to the control was derived by using the equation $2^{-\Delta \Delta C t}(18)$. The derived normalized values were the average of three runs.

Extraction and assay of plasma UII. Quantitative analysis of UII in plasma by ELISA was carried out using the procedure suggested in the Urotensin II (Human) ELISA kit (Phoenix Biotech Co., Ltd, Beijing, China). This showed cross-reactivity against ET-1 and angiotensin II, adrenomedullin, calcitonin gene-related peptide, pre-pro urotensin II and brain natriuretic peptide. All analysis was done in a single batch.

Reactivity of the antibodies was investigated with a competitive ELISA system, as described elsewhere (19), using biotinylated human UII and streptavidin conjugated with horseradish peroxidase (HRP) instead of HRP-labeled peptide.

In the ELISA, $50 \mu 1$ human II positive control in buffer and $50 \mu 1$ of sample solution or UII standard solution in buffer were added to wells of a microtiter plate that was precoated with secondary antibody, and incubated at room temperature $\left(20-23^{\circ} \mathrm{C}\right.$ ) for $2 \mathrm{~h}$. Then, $25 \mu \mathrm{l}$ of rehydrated biotinylated UII in buffer (provided in the kit) was added to each well and incubated at room temperature $\left(20-23^{\circ} \mathrm{C}\right)$ for $2 \mathrm{~h}$. After washing with PBS, $100 \mu 1$ /well of HRP-streptavidin in buffer (provided in the kit) was added to the plate and incubated for $1 \mathrm{~h}$. The plate was washed four times with PBS, and subsequently, $100 \mu 1 \mathrm{TMB}$ substrate solution was added to each well and incubated for $2 \mathrm{~h}$ in the dark. Reaction was stopped by adding $100 \mu \mathrm{l}$ of $2 \mathrm{~N} \mathrm{HCl}$, and absorbance was measured at $450 \mathrm{~nm}$ in a Microplate Reader Type 680 (BioRad Laboratories, Richmond, CA, USA). The intensity of absorbance was inversely proportional to the concentration of UII in the sample.

Measurement of free portal vein pressure (FPVP). FPVP was measured directly during the operation. A 20-cm-long rigid silica gel catheter, $0.2 \mathrm{~cm}$ in diameter was inserted through the right gastroepiploic vein into the portal vein. The catheter was fixed and connected with a monitor by a transducer. The patients were placed in the supine position, and the mid-axillary line was defined as the baseline for FPVP measurement. If there was a difference of $>1 \mathrm{~cm} \mathrm{H}_{2} \mathrm{O}$ between the readings, all the recordings were discarded and fresh readings were taken.

Immunohistochemistry. The paraffin-fixed samples were sliced into 4- $\mu$ m-thick sections and subjected to immunohistochemical staining using the EliVision ${ }^{\mathrm{TM}}$ Plus kit (Maxim Corp, Fuzhou, China), according to the manufacturer's protocol. Tissue sections were incubated with rabbit anti-UII receptor (human) antibody (1:200; LifeSpan BioSciences, Seattle, WA, USA) for $18 \mathrm{~h}$ in a moist chamber at $4^{\circ} \mathrm{C}$ and washed three times with PBS. An enhancer was added for $30 \mathrm{~min}$, which was followed by three washes in PBS, addition of HRP-conjugated goat antirabbit for $20 \mathrm{~min}$, and another three washes in PBS. Finally, immunoreactivity was visualized by reaction with diaminobenzidine (supplied ready-to-use, Maxim Corp., Fuzhou, China) for $10 \mathrm{~min}$, and counterstained with Mayer's hematoxylin. For a negative control, the primary antibodies were replaced with PBS. 
Table I. Patient clinical characteristics at the time of biopsy.

\begin{tabular}{lcc}
\hline Charateristics & $\begin{array}{c}\text { Patients } \\
(\mathrm{n}=23)\end{array}$ & $\begin{array}{c}\text { Normal Controls } \\
(\mathrm{n}=10)\end{array}$ \\
\hline Sex $(\mathrm{M} / \mathrm{F})$ & $16 / 7$ & $7 / 3$ \\
Age $(\mathrm{y})$ & $38 \pm 6.63$ & $51 \pm 10.04$ \\
Cause of cirrhosis & hepatitis B & $\mathrm{N}$ \\
No. with ascites & 4 & $\mathrm{~N}$ \\
Child-Pugh A/B/C & $19 / 4 / 0$ & $\mathrm{~N}$ \\
Mean arterial & $87.9 \pm 2.1$ & $93.9 \pm 4.31$ \\
blood pressure $(\mathrm{mmHg})$ & & \\
Bilirubin $(\mathrm{mol} / \mathrm{l})$ & $30.81 \pm 9.10$ & $6.30 \pm 2.98$ \\
Albumin $(\mathrm{g} / \mathrm{l})$ & $35.3 \pm 3.59$ & $41.8 \pm 1.93$ \\
Free portal & $29.31 \pm 2.40$ & $\mathrm{~N}$ \\
pressure $\left(\mathrm{cm} \mathrm{H}_{2} \mathrm{O}\right)$ & & \\
Urotensin $\mathrm{II}(\mathrm{ng} / \mathrm{ml})$ & $2.70 \pm 0.45$ & $1.57 \pm 0.50$ \\
\hline
\end{tabular}

Double staining. To indentify UT-positive cells, paraffin sections were double-stained using indirect immunofluorescence. UT/CD68 double staining was done with antiUT (GPR14, sc-20940; Santa Cruz Biotechnology, Santa Cruz, CA, USA) followed by FITC-conjugated anti-rabbit IgG (Zhongshan, Beijing, China) and anti-CD68 (Zhongshan) followed by TRITC-conjugated anti-mouse IgG (Zhongshan). UT/CD31 double staining was done with anti-UT followed by FITC-conjugated goat anti-rabbit IgG and anti-CD31 (Zhongshan) and TRITC-conjugated goat anti-mouse IgG. All staining experiments were done with appropriate positive and negative controls. Sections were analyzed by fluorescence microscopy (Olympus BX51 microscope). Colocalization of membrane staining (CD68/UT and CD31/UT) was visualized with image analysis software (Image Pro Plus, version 5.0; Media Cybernetics, Silver Spring, MD, USA) by applying the Boolean 'AND' operator. This operator combined individual unmixed images into a new image that consisted solely of colocalized (double-stained) pixels, thus representing doublestained cells only (yellow).

Western blot analysis. Protein was extracted from liver samples (Protein Extractor IV; DBI, Shanghai, China), homogenized, and assayed using the bicinchoninic acid method (Pierce BCA Protein Assay kit; Thermo Fisher Scientific Inc., Rockford, IL, USA). The $40-\mu \mathrm{g}$ protein samples were subjected to SDSPAGE ( $80 \mathrm{~V}$ for $40 \mathrm{~min}$ on a $5 \%$ acrylamide stacking gel and $120 \mathrm{~V}$ for $70 \mathrm{~min}$ on a $10 \%$ running gel), and then transferred (390 MA for $70 \mathrm{~min}$ ) to a nitrocellulose membrane (Hybond-C Extra Membrane 45, Amersham Biosciences, Uppsala, Sweden). The membranes were soaked in Tris-buffered saline $(10 \mathrm{mmol} / \mathrm{l}$ Tris- $\mathrm{HCl}$ and $250 \mathrm{~mol} / \mathrm{l} \mathrm{NaCl})$ that contained $5 \%$ non-fat powdered milk and $0.1 \%$ Tween-20 for $2 \mathrm{~h}$ to block nonspecific sites, and incubated with primary antibody, rabbit anti-human UT antibody (GPR14; Santa Cruz Biotechnology) overnight at $4^{\circ} \mathrm{C}$ in blocking solution. The resulting blots were washed and incubated with secondary antibody (HRP-linked goat anti-rabbit $\mathrm{IgG}$ ) for $2 \mathrm{~h}$ at room temperature. Immunoreactivity was visualized using an enhanced chemiluminescence kit (Thermo Fisher Scientific). Films were scanned using the
Table II. Primer sequences for human UII, UT, and GADPH.

\begin{tabular}{llcc}
\hline Gene & \multicolumn{1}{c}{$\begin{array}{c}\text { Primer } \\
\text { sequence }\end{array}$} & $\begin{array}{c}\text { Product } \\
\text { size (bp) }\end{array}$ & $\begin{array}{c}\text { Accession } \\
\text { number }\end{array}$ \\
\hline GADPH & $\begin{array}{l}\text { F: 5' AGCCACATC } \\
\text { GCTCAGACAC3' }\end{array}$ & 66 & NM_002046.3 \\
& R: 5' GCCCAATAC & & \\
& GACCAAATCC3' & & \\
UII & F: 5'CGTCTATCTT & 201 & NM_006786.2 \\
& GTGGCGATCA3' & & \\
& R: 5' CCCAGCATCT & & \\
UT & CTGGCAGTAT 3' & & \\
& F: 5' GTACGTCTAC & 67 & NM_018949.1 \\
& GTGGTCAACCTG3' & & \\
& R: 5'CACGATGA & & \\
& AGGGGATGCT3' & & \\
\hline
\end{tabular}

UII, urotensin II; UT, urotensin II receptor.

Bio-Rad imaging system. Antibody dilutions were as follows: rabbit polyclonal anti-UT antibody $(1: 1,000$; Santa Cruz Biotechnology) and HRP-linked goat anti-rabbit $\operatorname{IgG}(1: 5,000$; Immunology Consultants Laboratory Inc., Newberg, OR, USA). Proteins were detected via enhanced chemiluminescence (Thermo Fisher Scientific), and bands were quantified via scanning densitometry using the SCAN Control (Scanco-1.lnk) imaging system. Individual levels of GPR14 protein expression were normalized to $ß$-actin.

Statistical analysis. The results are expressed as mean \pm SD. Statistical analysis was performed using ANOVA and unpaired Student's t test as appropriate. $\mathrm{P}<0.05$ was considered statistically significant. The relationship between liver serum UII and FPVP was analyzed using the Pearson correlation coefficient. Statistical analyses were performed using SPSS version 17.0 (SPSS Inc., Chicago, IL, USA).

\section{Results}

Clinical data. Basic patient and control data are shown in Table I. All patients had evidence of cirrhosis by histopathological analysis. None of the patients had taken vasoactive drugs or somatostatin for 1 week before surgery. Blood pressure and portal pressure measured at the time of surgery are listed in Table I.

Liver UII and UT gene expression. Measurement of gene expression of UII with real-time PCR in RNA extracted from biopsy samples showed a 5-fold increase in UII mRNA compared with normal control samples (Fig. 1A). Similarly, measurement of UT expression showed an even more dramatic, 13.6-fold increase in expression in patients with cirrhosis and portal hypertension compared with normal control tissue (Fig. 2B).

Plasma UII levels and correlation with FPVP and UII mRNA. Plasma UII levels were significantly higher in patients with cirrhosis than in healthy controls $(\mathrm{P}<0.001$; Fig. 2A, Table I). 

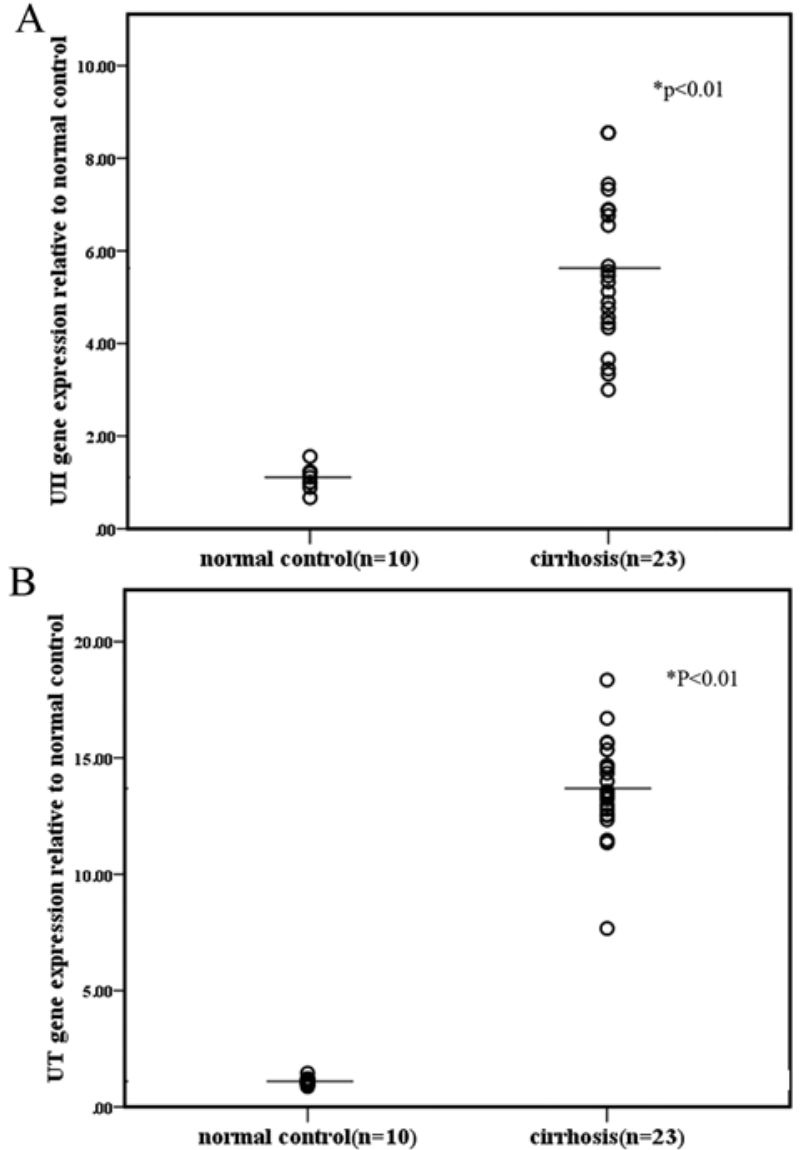

Figure 1. UII (A) and UT (B) mRNA in human liver tissue. mRNA was quantified in liver biopsy specimens from patients with cirrhosis and from normal living donors by real-time RT-PCR. Results are expressed as Ct for target gene standardized to $\mathrm{Ct}$ for the housekeeping gene GAPDH. Values expressed as mean $(95 \% \mathrm{CI})$ relative to the controls, which were arbitrarily assigned a value of $1 .{ }^{*} \mathrm{P}<0.01$ versus controls.

On the other hand, UII levels were correlated significantly with FPVP in patients with cirrhosis $(\mathrm{r}=0.807 ; \mathrm{P}<0.001 ; \mathrm{Y}(\mathrm{FPVP})=$ 18.954+0.616X (UII); Fig. 3). Plasma UII levels were correlated positively with UII mRNA in the liver $(\mathrm{r}=0.802$; $\mathrm{P}<0.001$; Fig. 2B).

Liver UT protein expression. Immunohistochemistry using anti-UT antibody showed little or no UT protein expression in the normal control liver. Occasionally, certain cell types, such as Kupffer cells and endothelial cells but not hepatocytes, expressed weak UT immunoreactivity (Fig. 4A and B). The liver of patients with cirrhosis and portal hypertension showed abundant UT protein expression, which was concentrated mainly in sinusoidal endothelial and Kupffer cells (Fig. 4C3 and C6). A $60-\mathrm{kDa}$ band, indicative of UT expression, was observed for the liver (Fig. 5A). Western blot analysis demonstrated a significant increase in UT protein expression in the liver of patients with cirrhosis compared with the controls (Fig. 5B).

\section{Discussion}

Recently, several studies have shown that UII plasma levels are increased in patients with liver cirrhosis and portal hypertension $(16,17)$. The UII plasma levels are correlated negatively
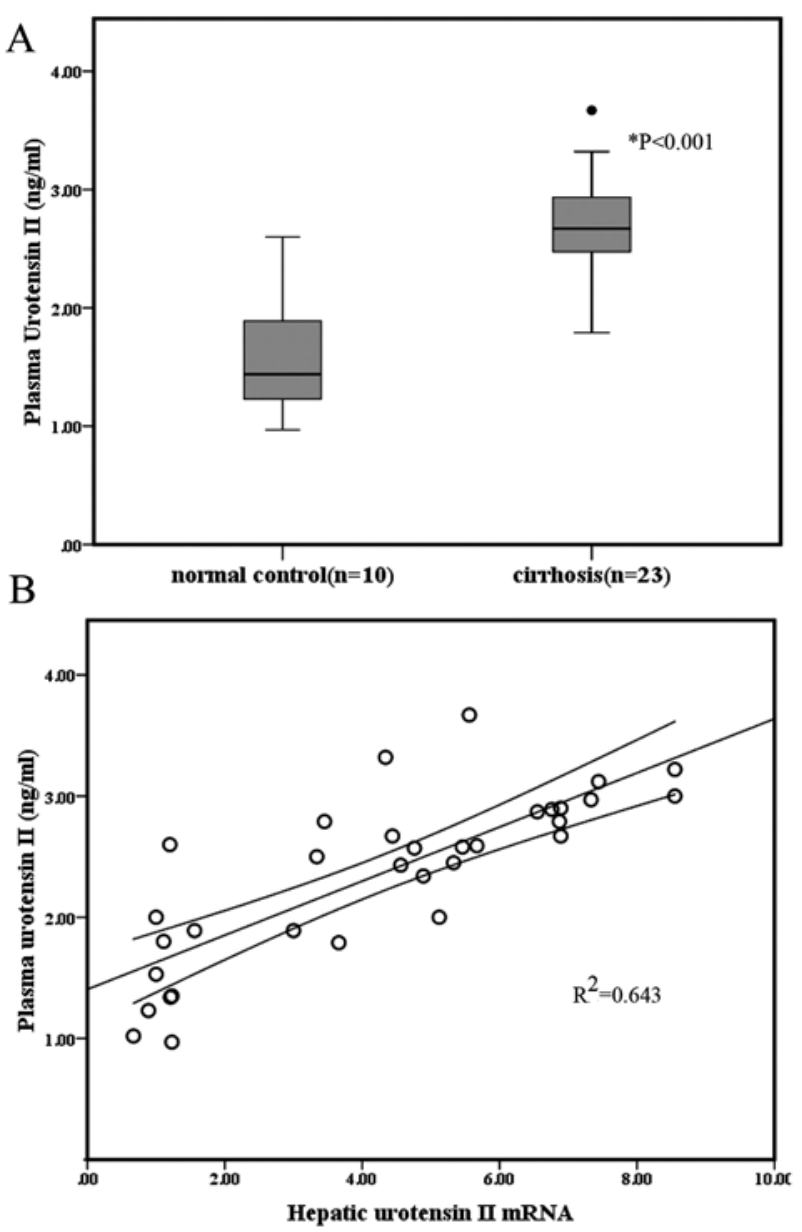

Figure 2. (A) UII plasma levels obtained from normal controls and 23 patients with cirrhosis and portal hypertension who were hemodynamically stable. Data are presented as the median. Plasma UII levels were significantly higher in patients with cirrhosis than in healthy controls $(\mathrm{P}<0.001)$. (B) Relationship of peripheral plasma UII levels and hepatic UII gene expression from 23 patients and 10 normal controls $\left(\mathrm{r}=0.802 ;{ }^{*} \mathrm{P}<0.001 ; \mathrm{R}^{2}=0.643\right)$.

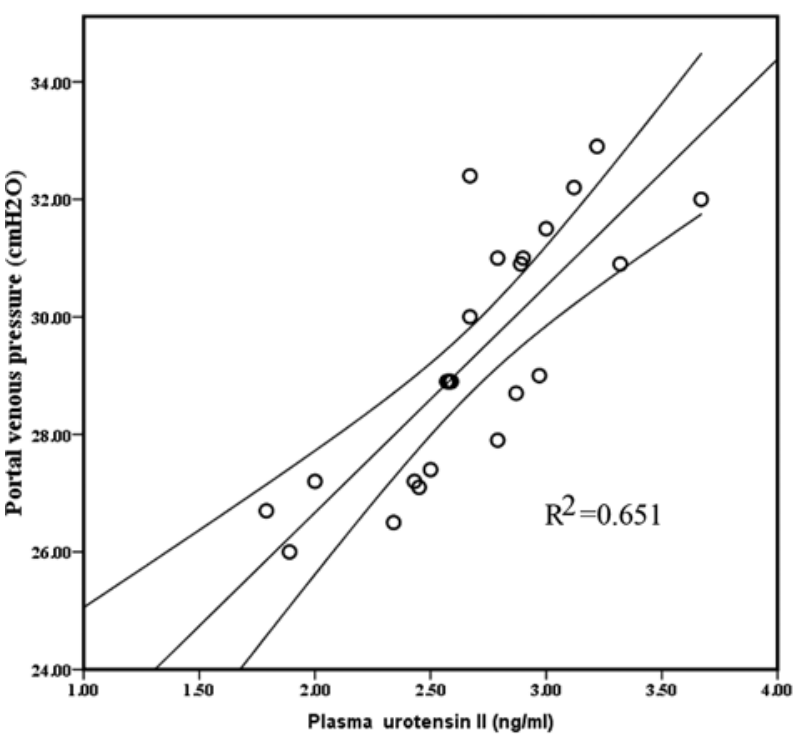

Figure 3. Correlation between UII plasma levels and FPVP obtained from 23 patients with cirrhosis $\left(\mathrm{r}=0.807\right.$; ${ }^{*} \mathrm{P}<0.01 ; \mathrm{R}^{2}=0.651$; Pearson correlation test). Single-dimensional linear-regression is $\mathrm{Y}(\mathrm{FPVP})=18.954+0.616 \mathrm{X}(\mathrm{UII})$. 

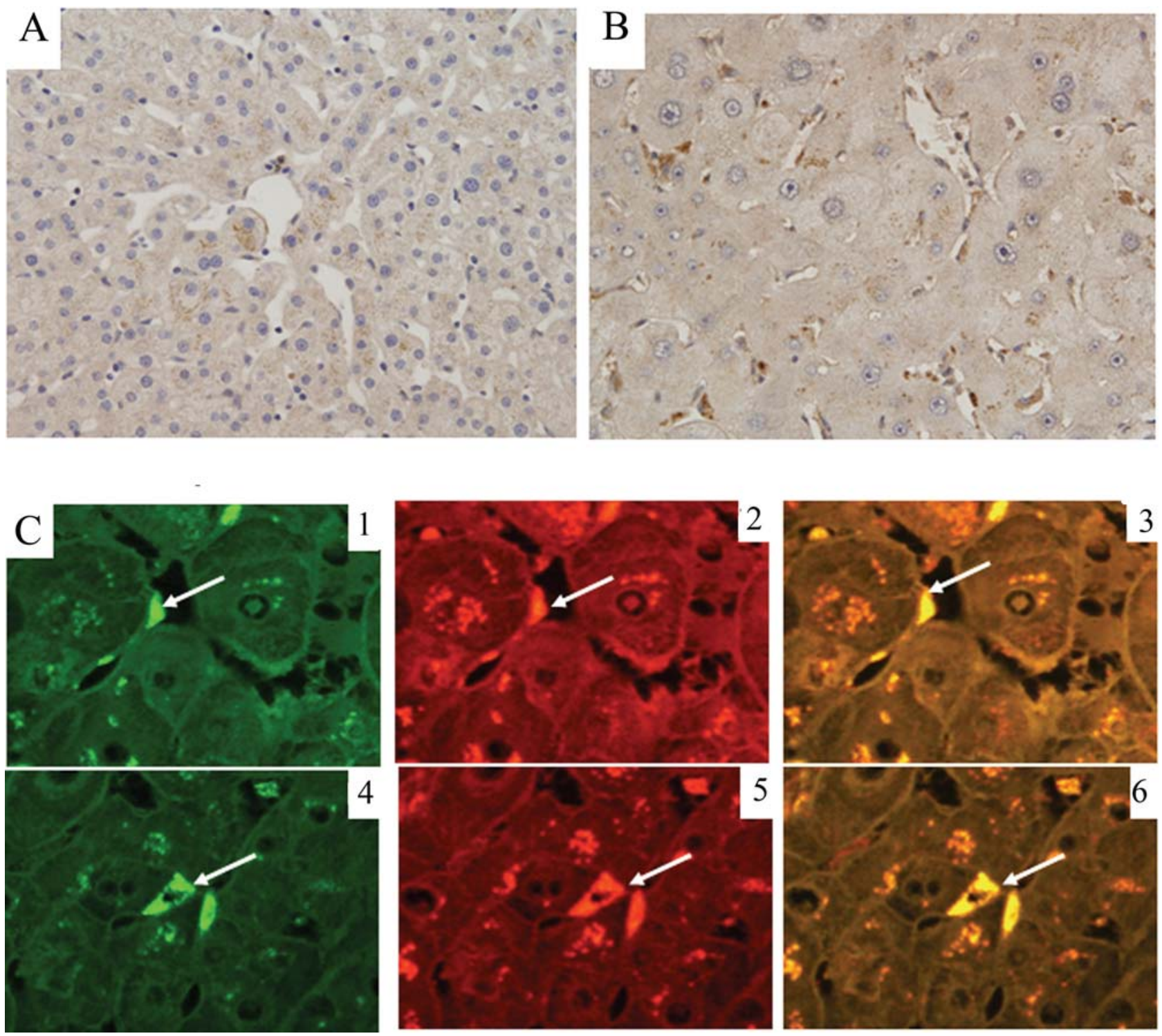

Figure 4. Immunohistochemical staining of UT protein in the liver of normal controls and patients with cirrhosis. In contrast to the little or no UT staining in the liver of normal controls (A), cirrhotic liver (B) displayed increased UT peptide expression. Co-localization experiments with UT (C1, arrow) and CD31 $(\mathrm{C} 2$, arrow) show that these cells were sinusoidal endothelial cells (C3, arrow). Co-localization experiments with UT (C4, arrow) and CD68 (C5, arrow) show that these cells were Kupffer cells (C6, arrow).
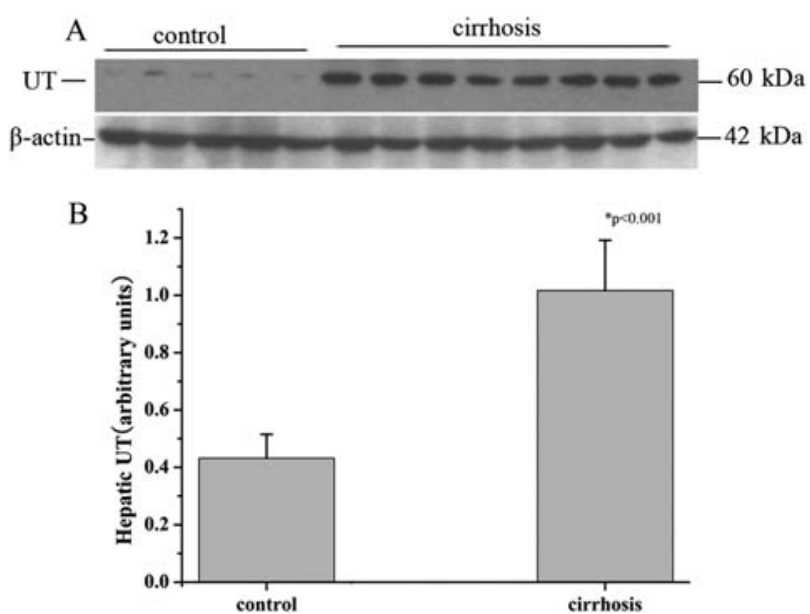

Figure 5. Protein expression of UT in the liver was determined by Western blotting in controls and patients with cirrhosis (A). Data were normalized to internal control (B-actin) and are expressed as the mean $\pm \mathrm{SD}^{*} \mathrm{p}<0.001$ (cirrhosis vs. control) (B). with mean arterial pressure and positively with portal pressure and severity of liver disease, as assessed using the Child-Pugh score $(16,17)$. However, the site of increased production of UII in patients with chronic liver disease remains unclear (9). In addition, there are no published studies that have assessed liver UII/UT while simultaneously performing detailed intraoperative FPVP measurement and collecting plasma for UII determination. The simultaneous sampling and measurement of UT and UII as described in the present study are a significant advance, because we were able to describe in detail the physiology and molecular biology in live human subjects.

The present study showed dramatic overexpression of liver UII and it receptor in patients with cirrhosis and portal hypertension, with a 5-fold increase in ligand gene expression and an $\sim 13$.6-fold increase in receptor expression. In addition, immunohistochemical studies and Western blot analysis showed increased expression of UT in human cirrhotic liver, which is consistent with our previous study and that by 
Tribeka et al in a rat model of cirrhosis (20,21). In apparent variance with our data, Leifeld et al have shown by immunohistochemistry that there was no significant difference in UII/UT between cirrhotic and control liver. There are likely to be many reasons for this disparity, including the diverse population group, rapid degradation of UII after its secretion, and marked differences in sensitivity and possibly specificity, between the UT assays $(16,17,22)$, and its probable autocrine/ paracrine mechanism of action $(23,24)$. Other differences, besides etiology, are the absence of portal hypertension and plasma UII measurements in the study of Leifeld et al. Patients with cirrhosis and ascites (as confirmation of portal hypertension) have higher UII levels than those without ascites (17). This phenomenon seems not to be a feature of cirrhosis, but of portal hypertension. Portal hypertension seems to induce vascular and hepatic upregulation of UT and fibrosis, as shown recently by Kemp et al (25). Furthermore, a limitation of our study is that the patients with cirrhosis and portal hypertension are only a fraction of all patients with cirrhosis.

Although liver tissue expression of UII/UT mRNA in patients with cirrhosis and portal hypertension has not been examined previously, other studies have assessed elevated plasma UII levels in patients with chronic liver disease and those with portal hypertension (17). However, because of the diverse population group and potential confounding variables such as hepatorenal syndrome, and hemodynamic instability secondary to variceal bleeding, it is difficult to determine to what extent the observed increase in UII levels is attributable directly to the underlying liver disease (9). For instance, Heller et al (17) have demonstrated increased levels of UII in their patients with cirrhosis. The trans-hepatic gradient between the hepatic and portal vein suggests hepatic production of this peptide. However, alternative sites of UII production, such as the splanchnic circulation or portal venous system, cannot be excluded. More recently, UII concentrations have been determined in blood from the femoral and hepatic veins in patients with stable cirrhosis, who were undergoing assessment of portal hemodynamics, and have been found to be higher in the femoral than the hepatic vein. Although this implies systemic overproduction of UII rather than increased hepatic output $(9,16)$, the data do not exclude the possibility of reduced hepatic clearance of UII. To address the issue of UII in the pathogenesis of portal hypertension, our group determined UII levels in patients with cirrhosis without hepatorenal syndrome, systemic hypertension, diabetes and hemodynamic instability secondary to variceal bleeding. UII levels in patients with heart failure, systemic hypertension, diabetes mellitus and renal failure are elevated $(14,15)$, therefore, patients with diabetes mellitus, chronic kidney disease, systemic hypertension, and aortic valvular disease were excluded. UII circulates in the human plasma and its concentration is measured by ELISA using specific antibodies. Here, consistent with the study of Heller et al (17), we found significantly higher UII levels in patients with cirrhosis than in healthy controls, and UII levels correlated positively with the degree of FPVP. Furthermore, the enhanced expression of hepatic UII mRNA was found to be associated more closely with circulating UII levels. Together, these findings indicate up-regulation of UII expression by the liver, which leads to the possible increased release of UII into the circulation, in patients with cirrhosis and portal hypertension.
Although recognized for its potent vasoconstrictive actions, the effects of UII, like ET, are highly contextual, with responses dependent on vessel size, anatomical location, and species studied (26). For instance, although UII is a potent vasoconstrictor in large vessels of rodents and non-human primates, it also causes vasodilation of human pulmonary vessels $(27,28)$. In humans, iontophoresed topical UII causes vasodilation in healthy controls but vasoconstriction in subjects with chronic heart failure (29) and hypertension (30). The difference is attributed to impaired endothelial function in patients, in whom endothelial cells normally produce nitric oxide and prostacyclin, which contribute to reduced vascular tone. In portal hypertension, however, NO is not produced in the presinusoidal system and its production is disturbed or substantially decreased in the sinusoidal/post sinusoidal area $(2,31)$. In cirrhosis, increased intrahepatic vascular resistance is thought to be mainly in the hepatic sinusoids (32). In the present study, the expression of liver UT was upregulated in cirrhosis. Our immunohistochemical studies showed localization of UT in sinusoidal lining cells. This raises the possibility that UII has pathophysiological relevance in the portal hypertensive population through its vasoactive properties in hepatic sinusoids.

To date, most studies that have examined UII and UT have focused on the cardiovascular system, in which it is viewed as a potential target for therapeutic modulation (33). Cardiac remodeling after myocardial infarction, like liver sinusoid remodeling in liver cirrhosis, is characterized by excessive deposition of extracellular matrix (ECM) (34). Consistent with this pathogenetic role, in vitro studies of cultured fibroblasts have shown that UII induces the expression of fibronectin and collagen, to an extent similar to the profibrotic peptide, angiotensin II (35). Furthermore, induction of UT overexpression leads to augmented collagenous matrix synthesis (35). We have investigated the ability of UT receptor antagonist SB-710411 to arrest fibrosis in a rat model of liver cirrhosis (20). Together, the studies suggest that dramatic upregulation of UII and its receptor in liver cirrhosis found in the present study may contribute directly to the pathogenesis of the matrix expansion in patients with cirrhosis.

At a cellular level, no study has examined the effects of UII on hepatic stellate cells (HSCs), which have contractile and fibrogenic properties, and are located in the persinusoidal space of Disse, which is the principal site of ECM production (36). Several vasoconstrictors are involved in HSC activation, proliferation and constriction $(6,37,38)$. UII is a potent vasoconstrictor peptide and its potency of vasoconstriction is one order of magnitude greater than that of ET-1 (39), UII induces proliferation of cultured fibroblasts and contraction of smooth muscle cells (40). It is speculated therefore, that UII is a stimulating factor for proliferation and contraction of HSCs. However, although the present study focused on biopsy specimens from patients with cirrhosis and portal hypertension, it is possible that the overexpression of UII in liver may not be of pathogenic significance. Additional studies to investigate the effect of UII on HSCs could help in establishing the role of UII in patients with cirrhosis and portal hypertension.

In summary, expression of UII and its receptor was dramatically increased in patients with cirrhosis and portal hypertension. Although the mechanism of action of UII 
requires further investigation, in the context of its known biological effects, these findings suggest that this newly described vasoactive peptide system has a role in the pathogenesis of portal hypertension. Inhibition of this system could affect the progression of portal hypertension and have great clinical significance.

\section{References}

1. Gupta TK, Toruner M and Groszmann RJ: Intrahepatic modulation of portal pressure and its role in portal hypertension. Role of nitricoxide. Digestion 59: 413-415, 1998.

2. Zipprich A: Hemodynamics in the isolated cirrhotic liver. J Clin Gastroenterol 41 (Suppl 3): 254-258, 2007.

3. Bathal PS and Grossmann HJ: Reduction of the increased portal vascular resistance of the isolated perfused cirrhotic rat liver by vasodilators. J Hepatol 1: 325-329, 1985.

4. Cichoz-Lach H, Celinski K, Slomka M and KasztelanSzczerbinska B: Pathophysiology of portal hypertension. J Physiol Pharmacol 59 (Suppl 2): 231-238, 2008.

5. Rockey DC, Fouassier L, Chung JJ, Carayon A, Vallee P, Rey C and Housset C: Cellular localization of endothelin-1 and increased production in liver injury in the rats: potential for autocrine and paracrine effects on stellate cells. Hepatology 27: 472-480, 1998.

6. Gatta A, Bolognesi M and Merkel C: Vasoactive factors and hemodynamic mechanisms in the pathophysiology of portal hypertension in cirrhosis. Mol Aspects Med 29: 119-129, 2008.

7. Debernardi-Venon W, Martini S, Biasi F, Vizio B, Termine A, Poli G, Brunello F, Alessandria C, Bonardi R, Saracco G, Rizzetto M and Marzano A: AT1 receptor antagonist Candesartan in selected cirrhotic patients: effect on portal pressure and liver fibrosis markers. J Hepatol 46: 1026-1033, 2007.

8. Ames RS, Sarau HM, Chambers JK, Willette RN, Aiyar NV, Romanic AM, Louden CS, Foley JJ, Sauermelch CF, Coatney RW, Ao Z, Disa J, Holmes SD, Stadel JM, Martin JD, Liu WS Glover GI, Wilson S, McNulty DE, Ellis CE, Elshourbagy NA, Shabon U, Trill JJ, Hay DW, Ohlstein EH, Bergsma DJ and Douglas SA: Human urotensin-II is a potent vasoconstrictor and agonist for the orphan receptor GPR14. Nature 401: 282-286, 1999.

9. Kemp W, Roberts $S$ and Krum H: Increased circulating urotensin II in cirrhosis: potential implications in liver disease. Peptides 29: 868-872, 2008.

10. Zhang YG, Li YG, Liu BG, Wei RH, Wang DM, Tan XR, Bu DF, Pang YZ and Tang CS: Urotensin II accelerates cardiac fibrosis and hypertrophy of rats induced by isoproterenol. Acta Pharmacol Sin 28: 36-43, 2007

11. Russell FD: Urotensin II in cardiovascular regulation. Vasc Health Risk Manag 4: 775-785, 2008.

12. Conlon JM, Yano K, Waugh D and Hazon N: Distribution and molecular forms of urotensin II and its role in cardiovascular regulation in vertebrates. J Exp 275: 226-238, 1996.

13. Behm DJ, Harrison SM, Ao Z, Maniscalco K, Pickering SJ Grau EV, Woods TN, Coatney RW, Doe CP, Willette RN, Johns DG and Douglas SA: Deletion of the UT receptor gene results in the selective loss of urotensin-II contractile activity in aortae isolated from UT receptor knockout mice. Br J Pharmacol 139: 464-472, 2003.

14. Richards AM, Nicholls MG, Lainchbury JG, Fisher S and Yandle TG: Plasma urotensin II in heart failure. Lancet 360: 545-546, 2002.

15. Russell FD, Meyers D, Galbraith AJ, Bett N, Toth I, Kearns P and Molenaar P: Elevated plasma levels of human urotensin-II immunoreactivity in congestive heart failure. Am J Physiol Heart Circ Physiol 285: H1576-H1581, 2003.

16. Kemp W, Krum H, Colman J, Bailey M, Yandle T, Richards M and Roberts S: Urotensin II: a novel vasoactive mediator linked to chronic liver disease and portal hypertension. Liver Int 27: 1232-1239, 2007.

17. Heller J, Schepke M, Neef M, Woitas R, Rabe C and Sauerbruch T: Increased urotensin II plasma levels in patients with cirrhosis and portal hypertension. J Hepatol 37: 767-772, 2002.

18. Livak KJ and Schmittgen TD: Analysis of relative gene expression data using real-time quantitative PCR and the 2(-Delta Delta C (T)) method. Methods 25: 402-408, 2001.

19. Porstmann T and Kiessig ST: Enzyme immunoassay techniques: an overview. J Immunol Methods 150: 5-21, 1992.
20. Liu DG, Wang J, Zhang ZT and Wang Y: The urotensin II antagonist SB-710411 arrests fibrosis in CCL4 cirrhotic rats. Mol Med Rep 2: 953-961, 2009.

21. Trebicka J, Leifeld L, Hennenberg M, Biecker E, Eckhardt A, Fischer N, Pröbsting AS, Clemens C, Lammert F, Sauerbruch T and Heller J: Hemodynamic effects of urotensin II and its specific receptor antagonist palosuran in cirrhotic rats. Hepatology 47: 1264-1276, 2008.

22. Leifeld L, Clemens C, Heller J, Trebicka J, Sauerbruch T and Spengler U: Expression of urotensin II and its receptor in human liver cirrhosis and fulminant hepatic failure. Dig Dis Sci (In press).

23. Zhang Y, Li Y, Wei R, Wang Z, Bu D, Zhao J, Pang Y and Tang C: Urotensin II is an autocrine/paracrine growth factor for aortic adventitia of rat. Regul Pept 151: 88-94, 2008.

24. Matsushita M, Shichiri M, Fukai N, Ozawa N, Yoshimoto T, Takasu N and Hirata Y: Urotensin II is an autocrine/paracrine growth factor for the porcine renal epithelial cell line, LLCPK1. Endocrinology 144: 1825-1831, 2003.

25. Kemp W, Kompa A, Phrommintikul A, Herath C, Zhiyuan J, Angus P, McLean C, Roberts S and Krum H: Urotensin II modulates hepatic fibrosis and portal hemodynamic alterations in rats. Am J Physiol Gastrointest Liver Physiol 297: G762-G767, 2009.

26. Douglas SA, Ashton DJ, Sauermelch CF, Coatney RW, Ohlstein DH, Ruffolo MR, Ohlstein EH, Aiyar NV and Willette RN: Human urotensin-II is a potent vasoactive peptide: Pharmacological characterization in the rat, mouse, dog and primate. J Cardiovasc Pharmacol 36: S163-S166, 2000.

27. Stirrat A, Gallagher M, Douglas SA, Ohlstein EH, Berry C, Kirk A, Richardson M and MacLean MR: Potent vasodilator responses to human urotensin-II in human pulmonary and abdominal resistance arteries. Am J Physiol Heart Circ Physiol 280: H925-H928, 2001.

28. Bottrill FE, Douglas SA, Hiley CR and White R: Human urotensin-II is an endothelium-dependent vasodilator in rat small arteries. Br J Pharmacol 30: 1865-1870, 2000.

29. Lim M, Honisett S, Sparkes CD, Komesaroff P, Kompa A and Krum H: Differential effect of urotensin II on vascular tone in normal subjects and patients with chronic heart failure. Circulation 109: 1212-1214, 2004

30. Sondermeijer B, Kompa A, Komesaroff P and Krum H: Effect of exogenous urotensin-II on vascular tone in skin microcirculation of patients with essential hypertension. Am J Hypertens 18: 1195-1199, 2005.

31. Loureiro-Silva MR, Cadelina GW and Groszmann RJ: Deficit in nitric oxide production in cirrhotic rat livers is located in the sinusoidal and postsinusoidal areas. Am J Physiol Gastrointest Liver Physiol 284: G567-G574, 2003.

32. Bosch J and Garcia-Pagan JC: Complications of cirrhosis. I. Portal hypertension. J Hepatol 32: 141-156, 2000.

33. Douglas SA: Human urotensin-II as a novel cardiovascular target: 'Heart' of the matter or simply a fishy 'tail'? Curr Opin Pharmacol 3: 159-167, 2003.

34. Parsons CJ, Takashima M and Rippe RA: Molecular mechanisms of hepatic fibrogenesis. J Gastroenterol Hepatol 22: S79-S84, 2007.

35. Tzanidis A, Hannan RD, Thomas WG, Onan D, Autelitano DJ, See F, Kelly DJ, Gilbert RE and Krum H: Direct actions of urotensin II on the heart: Implications for cardiac fibrosis and hypertrophy. Circ Res 93: 246-253, 2003.

36. Moreira RK: Hepatic stellate cells and liver fibrosis. Arch Pathol Lab Med131: 1728-1734, 2007.

37. Bataller R, Ginès P, Nicolás JM, Görbig MN, Garcia-Ramallo E, Gasull X, Bosch J, Arroyo V and Rodés J: Angiotensin II induces contraction and proliferation of human hepatic stellate cells. Gastroenterology 118: 1149-1156, 2000.

38. Mallat A: Hepatic stellate cells and intrahepatic modulation of portal pressure. Digestion 59: 416-419, 1998.

39. Douglas SA, Sulpizio AC, Piercy V, Sarau HM, Ames RS, Aiyar NV, Ohlstein EH and Willette RN: Differential vasoconstrictor activity of human urotensin-II in vascular tissue isolated from the rat, mouse, dog, pig, marmoset and cynomolgus monkey. Br J Pharmacol 131: 1262-1274, 2000.

40. Tamura K, Okazaki M, Tamura M, Isozumi K, Tasaki $\mathrm{H}$ and Nakashima Y: Urotensin II-induced activation of extracellular signal-regulated kinase in cultured vascular smooth muscle cells: involvement of cell adhesion-mediated integrin signaling. Life Sci 72: 1049-1060, 2003. 